This item was submitted to Loughborough's Research Repository by the author.

Items in Figshare are protected by copyright, with all rights reserved, unless otherwise indicated.

\title{
Activation of hydrogen peroxide by diphenyl diselenide for highly enantioselective oxaziridinium salt mediated catalytic asymmetric epoxidation
}

\section{PLEASE CITE THE PUBLISHED VERSION}

http://dx.doi.org/10.1055/s-0033-1339681

\section{PUBLISHER}

(c) Georg Thieme Verlag KG

\section{VERSION}

AM (Accepted Manuscript)

\section{LICENCE}

CC BY-NC-ND 4.0

\section{REPOSITORY RECORD}

Buckley, Benjamin R., Claire Elliott, Yohan Chan, Nicholas Dreyfus, and Philip C. Bulman Page. 2019. "Activation of Hydrogen Peroxide by Diphenyl Diselenide for Highly Enantioselective Oxaziridinium Salt Mediated Catalytic Asymmetric Epoxidation”. figshare. https://hdl.handle.net/2134/13944. 
This item was submitted to Loughborough's Institutional Repository (https://dspace.lboro.ac.uk/) by the author and is made available under the following Creative Commons Licence conditions.

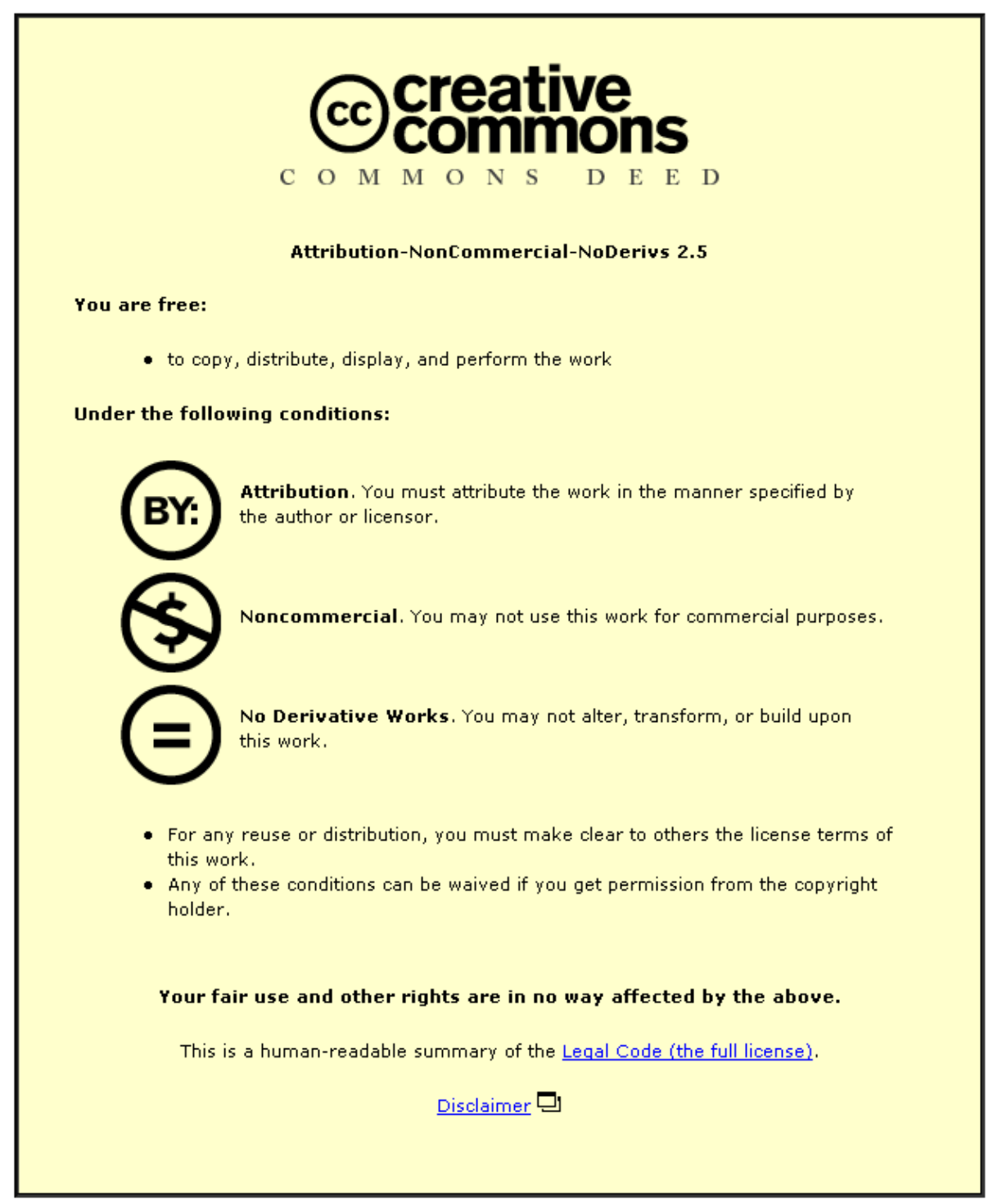

For the full text of this licence, please go to: http://creativecommons.org/licenses/by-nc-nd/2.5/ 


\title{
Activation of Hydrogen Peroxide by Diphenyl Diselenide for Highly Enanti- oselective Oxaziridinium Salt-Mediated Catalytic Asymmetric Epoxidation
}

\author{
Benjamin R. Buckley, ${ }^{a *}$ Claire E. Elliott, ${ }^{a}$ Yohan Chan, ${ }^{b}$ Nicholas Dreyfus, ${ }^{c}$ Philip C. Bulman Page ${ }^{b *}$ \\ ${ }^{a}$ Department of Chemistry, Loughborough University, Ashby Road, Loughborough, Leicestershire, LE11 3TU, UK. \\ ${ }^{\mathrm{b}}$ School of Chemistry, University of East Anglia, Norwich, Norfolk NR4 7TJ, UK. \\ ${ }^{\mathrm{c}}$ Eli Lilly, Erl Wood Manor, Erl Wood, Windlesham, Surrey, UK. \\ Fax: +44 (0)1509 223925 \\ E-mail: b.r.buckley@lboro.ac.uk or p.page@uea.ac.uk
}

Received: The date will be inserted once the manuscript is accepted.

Abstract: The first reported use of benzeneperseleninic acid as a catalytic mediator for oxaziridinium ion catalysed epoxidation is described, providing reaction rates and ees (up to $85 \%$ ) similar to those reported when using oxone as the stoicheiometric oxidant. A dual catalytic cycle is proposed, in which diphenydiselenide is initially converted into the perseleninic acid, which in turn oxidizes an iminium ion to the corresponding oxaziridium species, thus facilitating asymmetric oxygen transfer to an alkene.

Key words: Epoxidation, Iminium salt, Oxaziridinium, Diphenyldiselenide, Oxidation.

Oxaziridinium salts have emerged as highly active species for the asymmetric epoxidation of unfunctionalized alkenes. $\mathrm{We}^{1}$ and others ${ }^{2}$ have reported a range of exo- and endo- cyclic iminium salt pre-catalysts that when treated with oxone undergo oxidation to the corresponding oxaziridinium salts, which are then able to transfer oxygen to alkenes (Scheme 1).

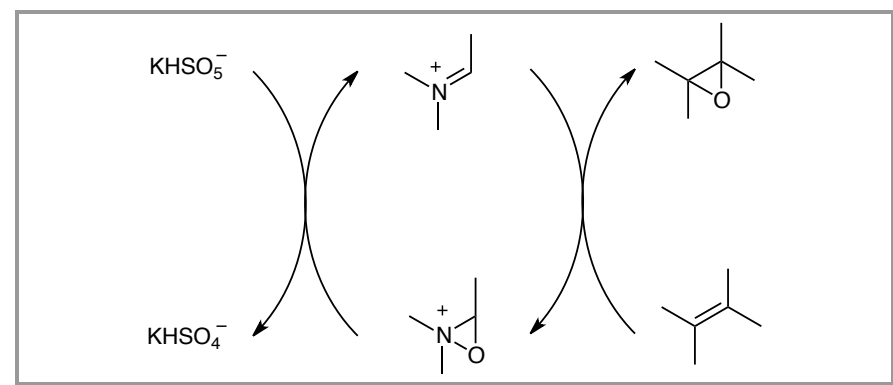

Scheme 1: General catalytic cycle involving oxaziridinium salts

The standard conditions employed in asymmetric epoxidation reactions catalysed by oxaziridinium salts involve the use of oxone as stoicheiometric oxidant, a base (typically 2 molar equivalents of $\mathrm{Na}_{2} \mathrm{CO}_{3}$ per equivalent of oxone), and water/acetonitrile as solvent mixture (Scheme 2): ${ }^{3}$ the presence of water is essential for oxone solubility. Under the reaction conditions, there are separate aqueous and organic phases; it is possible that the catalyst acts as a phase transfer agent under these reactions.

$$
\overbrace{\mathrm{R}^{2}}^{\mathrm{R}^{3}} \frac{\begin{array}{l}
\text { Iminium salt }(0.1-10 \mathrm{~mol} \%) \\
\text { Oxone }(2 \mathrm{eq}), \mathrm{Na}_{2} \mathrm{CO}_{3}(4 \mathrm{eq})
\end{array}}{\mathrm{CH}_{3} \mathrm{CN}: \mathrm{H}_{2} \mathrm{O}(1: 1), 0^{\circ} \mathrm{C} .}
$$

Scheme 2: The standard conditions applied for catalytic asymmetric epoxidation mediated by oxone and iminium salts.

The principal limitation to this system is the restricted range of temperatures at which the epoxidation can be per- formed (a little below $0{ }^{\circ} \mathrm{C}$ to room temperature). The upper limit is determined by the oxone, which decomposes relatively quickly in the basic medium at room temperature. The lower limit is determined by the use of the aqueous medium; one typical ratio of the water and acetonitrile cosolvents used is $1: 1$, and this mixture freezes at around -8 ${ }^{\circ} \mathrm{C}$.

One potential opportunity to enhance the enantioselectivity of the oxidation process would be provided if the reaction could be carried out at lower temperatures. This would require the development of non-aqueous reaction conditions, and, because of the solubility profile of oxone, which has no significant solubility in any organic solvent, this in turn dictates a need for a new stoicheiometric oxidant, soluble in organic solvents at low temperatures. Crucially, this oxidant must not itself oxidize alkenes under the reaction conditions in the absence of the catalyst (background, nonenantioselective, oxidation).

Towards this end we have reported the use of tetraphenylphosphonium monoperoxysulfate (TPPP) (originally reported by Di Furia in 1994 for oxygen transfer to manganese porphyrins), ${ }^{5}$ which has proved to be an excellent oxidant for highly enantioselective epoxidations. ${ }^{6}$ For example, epoxidation of $c i s$-alkene $\mathbf{1}$ affords the corresponding epoxide 2 with $97 \%$ ee when employing iminium salt 3 (Scheme 3). ${ }^{7}$ This system has since been used for the highly enantioselective total syntheses of levcromakalim [(-)cromakalim $],{ }^{7} \quad(-)-\left(3^{\prime} S\right)$-lomatin, ${ }^{8} \quad(+)-(3 ' S, 4$ 'R $)$-transkhellactone, ${ }^{8}$ and $(+)$-scuteflorin ${ }^{9}$ (Figure 1).

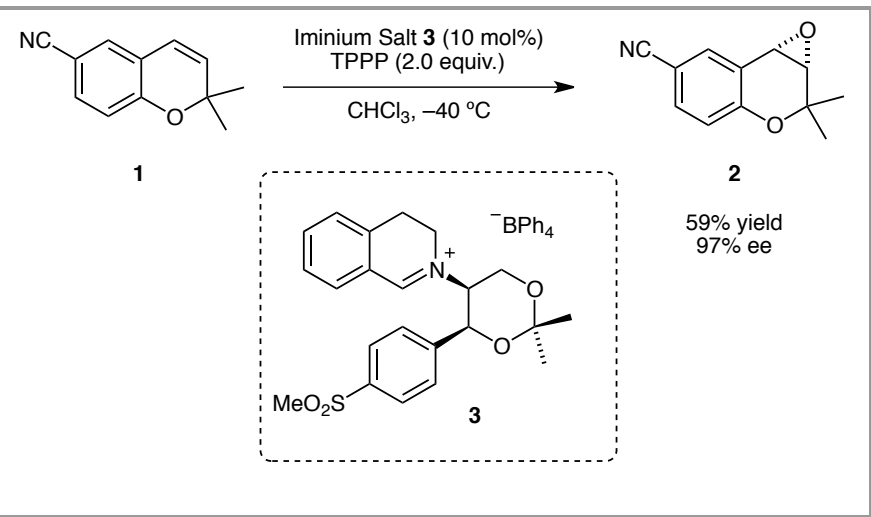

Scheme 3: Highly enantioselective epoxidation of cis- alkenes such as 1 mediated by iminium salt 3 .

We have also reported the use of hydrogen peroxide- ${ }^{10}$ and sodium hypochlorite- ${ }^{11}$ driven systems for asymmetric oxaziridinium salt-mediated epoxidation. 


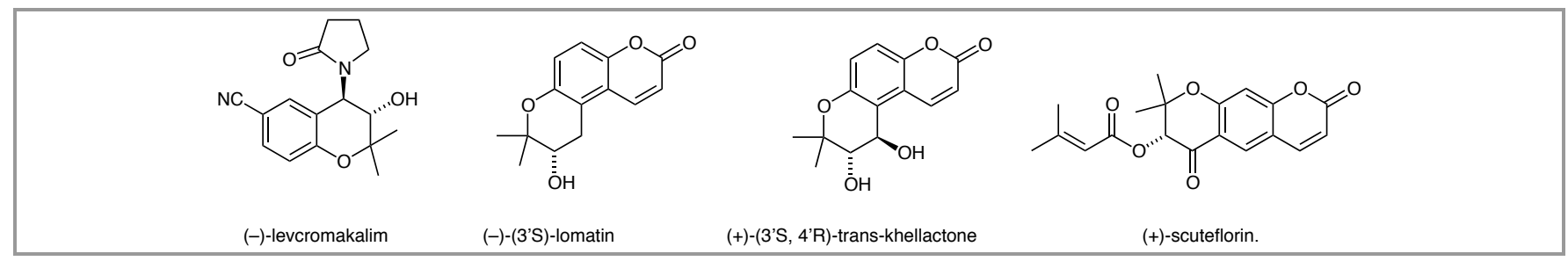

Figure 1

Table 1 A comparison of epoxidation conditions for 1-phenylcyclohexene and iminium salt 4.

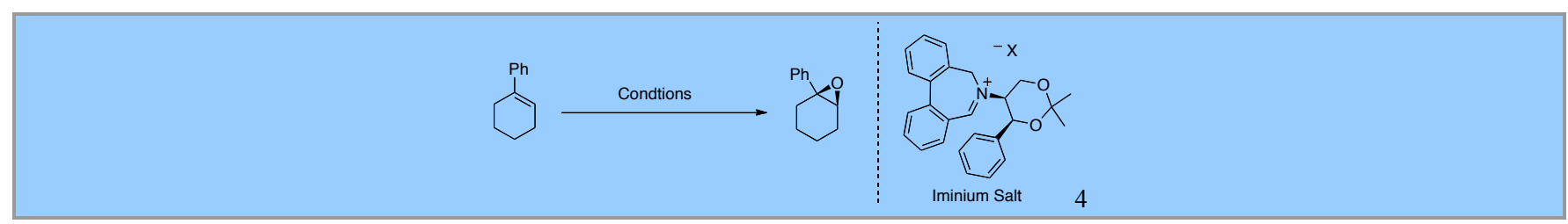

\begin{tabular}{|c|c|c|c|c|c|}
\hline Entry & Conditions & Time (h) & Conv. $(\%)^{\mathrm{a}}$ & ee $(\%)^{b}$ & ref \\
\hline 1 & $\begin{array}{l}\text { Iminium salt } 4(10 \mathrm{~mol} \%), \mathrm{X}=\mathrm{BPh}_{4} \text {, Oxone (2.0 equiv.), } \mathrm{Na}_{2} \mathrm{CO}_{3} \\
\text { (2.0 equiv.), } \mathrm{MeCN} / \mathrm{H}_{2} \mathrm{O}(1: 1), 0^{\circ} \mathrm{C}\end{array}$ & 0.30 & 100 & 60 & 1(a) \\
\hline 2 & $\begin{array}{l}\text { Iminium salt } 4 \text { ( } 5 \text { mol\%) } \mathrm{X}=\text { TRISPHAT, Oxone ( } 1.0 \text { equiv. }), \\
\mathrm{NaHCO}_{3}(4.0 \text { equiv. }), 18-\mathrm{C}-6(2.5 \mathrm{~mol} \%), \mathrm{CH}_{2} \mathrm{Cl}_{2} / \mathrm{H}_{2} \mathrm{O}(3: 2), 0 \\
{ }^{\circ} \mathrm{C} \text {. }\end{array}$ & 3.0 & 90 & 69 & 2(q) \\
\hline 3 & $\begin{array}{l}\left.\text { Iminium salt } 4(10 \mathrm{~mol} \%), \mathrm{X}=\mathrm{BPh}_{4}, \mathrm{TPPP} \text { ( } 2.0 \text { equiv. }\right), \mathrm{MeCN} \text {, } \\
0^{\circ} \mathrm{C}\end{array}$ & 0.03 & 100 & 58 & 6 \\
\hline 4 & $\begin{array}{l}\text { Iminium salt } 4 \text { ( } 10 \mathrm{~mol} \%), \mathrm{X}=\mathrm{BPh}_{4}, \mathrm{H}_{2} \mathrm{O}_{2}(50 \%, 6.0 \text { equiv. }) \text {, } \\
\mathrm{NaHCO}_{3}\left(0.2 \text { equiv), MeCN: } \mathrm{H}_{2} \mathrm{O}(9: 1), 0{ }^{\circ} \mathrm{C} .\right.\end{array}$ & 24 & 48 & 36 & 10 \\
\hline 5 & $\begin{array}{l}\text { Iminium salt } 4 \text { (10 mol\%), } \mathrm{X}=\mathrm{BPh}_{4} \text {, sodium hypochlorite }(6.0 \\
\text { equiv. }), \mathrm{K}_{2} \mathrm{CO}_{3}(0.25 \text { equiv }), \mathrm{MeCN}, 0^{\circ} \mathrm{C} \text {. }\end{array}$ & 24 & 100 & 55 & 11 \\
\hline 6 & $\begin{array}{l}\text { Iminium salt } 4(5 \mathrm{~mol} \%), \mathrm{X}=\mathrm{BPh}_{4}, \mathrm{H}_{2} \mathrm{O}_{2}(50 \%, 3.0 \text { equiv. }) \text {, } \\
\mathrm{PhSe}_{2}(5.0 \mathrm{~mol} \%), \mathrm{MeCN}, 0{ }^{\circ} \mathrm{C} \text {. }\end{array}$ & 0.30 & 100 & 50 & $\begin{array}{l}\text { This } \\
\text { work }\end{array}$ \\
\hline 7 & $\begin{array}{l}\text { Iminium salt } 4(5 \mathrm{~mol} \%), \mathrm{X}=\mathrm{BPh}_{4}, \mathrm{H}_{2} \mathrm{O}_{2}(50 \%, 3.0 \text { equiv. }) \text {, } \\
\mathrm{PhSe}_{2}(1.0 \mathrm{~mol} \%), \mathrm{MeCN}, 0{ }^{\circ} \mathrm{C} \text {. }\end{array}$ & 0.35 & 100 & 47 & $\begin{array}{l}\text { This } \\
\text { work }\end{array}$ \\
\hline 8 & $\mathrm{H}_{2} \mathrm{O}_{2}(50 \%, 3.0$ equiv. $), \mathrm{PhSe}_{2}(1.0 \mathrm{~mol} \%), \mathrm{MeCN}, 0{ }^{\circ} \mathrm{C}$ & 24 & $<5$ & - & $\begin{array}{l}\text { This } \\
\text { work }\end{array}$ \\
\hline
\end{tabular}

${ }^{a}$ Conversion evaluated by comparison of the alkene vs epoxide $\mathrm{CH}$ signals in the ${ }^{1} \mathrm{H}$ NMR spectrum; ${ }^{\mathrm{b}}$ ee determined by Chiral $\mathrm{GC}^{\mathrm{c}}$ ee determined by ${ }^{1} \mathrm{H}$ NMR spectroscopy in $\mathrm{CDCl}_{3}$ using $\left[(+)-\mathrm{Eu}(\mathrm{hfc})^{3}\right]$ as the chiral shift reagent and tetramethylsilane as the internal standard

Both systems suffer from reduced rates of reaction and lower ees when compared to the original oxonemediated processes. We were intrigued by the report of $\mathrm{Du}$ Bois regarding the use of a diarylselenide and hydrogen peroxide as a stoicheiometric oxidant for oxaziridine-mediated catalysis (Scheme 4). ${ }^{12}$ However, this system required the use of the bis(3,5bis(trifluoromethyl)phenyl) diselenide $\left(\mathrm{ArSe}_{2}\right)$, which is not commercially available and must be prepared using the procedure reported by ten Brink. ${ }^{13}$ The optimized system also employs urea-hydrogen peroxide as oxidant (water must to be excluded from this process to prevent hydrolysis of the parent imine).

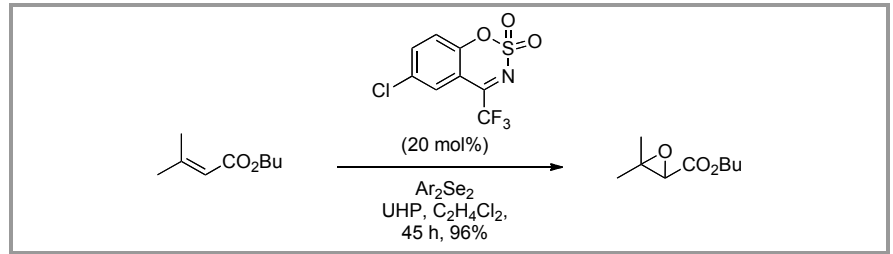

Scheme 4 Du Bois' oxaziridine catalysed oxidation

We began our studies using commercially available diphenyldiselenide $(5 \mathrm{~mol} \%)$ and aqueous hydrogen peroxide $(50 \%, 3.0$ equiv. $)$ in combination with our iminium salt catalysts, and were delighted to find that under these simple conditions rapid conversion of 1-phenylcyclohexene to epoxide was observed when using catalyst 4 . Reducing the loading of diphenyldiselenide to $1 \mathrm{~mol} \%$ appeared to have little effect on the rate of reaction, and this appears to be comparable to that of the aqueous oxone system. Table 1 provides a comparison of various sets of reaction conditions drawn from our own work and that of others. It can be seen 


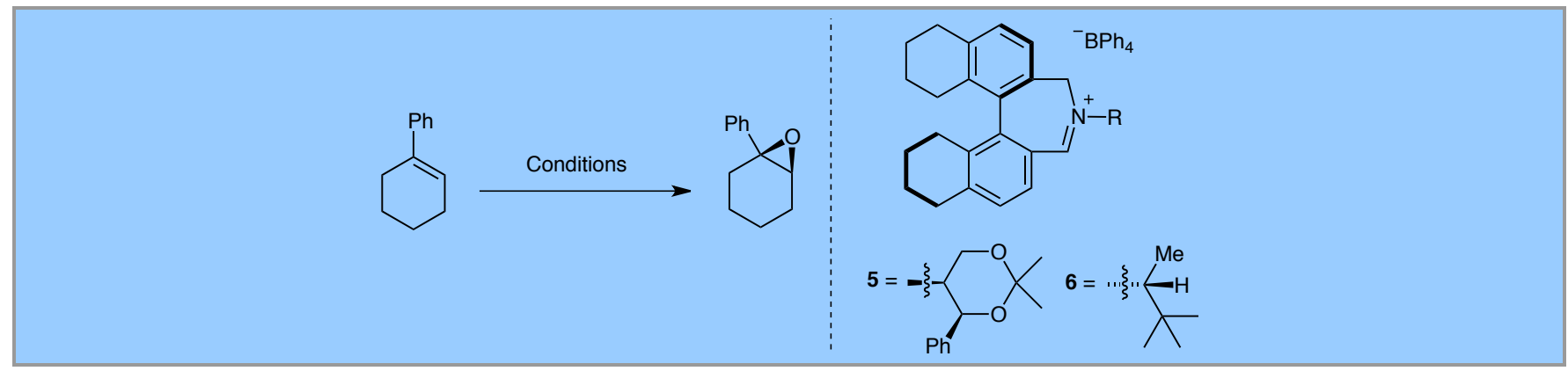

\begin{tabular}{|c|c|c|c|c|c|}
\hline Entry & Conditions & Catalyst & Time (h) & Conv. $(\%)^{\mathrm{a}}$ & $\begin{array}{l}\text { ee } \\
(\%)^{b}\end{array}$ \\
\hline 1 & $\begin{array}{l}\text { Iminium salt } 5 \text { ( } 5 \mathrm{~mol} \%), \mathrm{X}=\mathrm{BPh}_{4}, \text { Oxone }(2.0 \text { equiv. }) \text {, } \\
\mathrm{Na}_{2} \mathrm{CO}_{3}(2.0 \text { equiv. }), \mathrm{MeCN} / \mathrm{H}_{2} \mathrm{O}(1: 1), 0^{\circ} \mathrm{C}\end{array}$ & 3 & 2 & 75 & $88^{c}$ \\
\hline 2 & $\begin{array}{l}\text { Iminium salt } 5(5 \mathrm{~mol} \%), \mathrm{X}=\mathrm{BPh}_{4}, \mathrm{H}_{2} \mathrm{O}_{2}(50 \%, 3.0 \\
\text { equiv. }), \mathrm{PhSe}_{2}(1.0 \mathrm{~mol} \%), \mathrm{MeCN}, 0^{\circ} \mathrm{C} .\end{array}$ & 3 & 2 & 76 & 85 \\
\hline 3 & $\begin{array}{l}\text { Iminium salt } 6 \text { ( } 5 \text { mol\%) } \mathrm{X}=\mathrm{BPh}_{4}, \text { Oxone }(1.0 \text { equiv. }) \\
\left.\mathrm{NaHCO}_{3} \text { ( } 4.0 \text { equiv. }\right), 18-\mathrm{C}-6(2.5 \mathrm{~mol} \%), \mathrm{CH}_{2} \mathrm{Cl}_{2} / \mathrm{H}_{2} \mathrm{O} \\
(3: 2), 0{ }^{\circ} \mathrm{C} \text {. }\end{array}$ & 4 & 4 & 76 & 85 \\
\hline 4 & $\begin{array}{l}\text { Iminium salt } 6(5 \mathrm{~mol} \%), \mathrm{X}=\mathrm{BPh}_{4}, \mathrm{H}_{2} \mathrm{O}_{2}(50 \%, 3.0 \\
\text { equiv. }), \mathrm{PhSe}_{2}(1.0 \mathrm{~mol} \%), \mathrm{MeCN}, 0{ }^{\circ} \mathrm{C} \text {. }\end{array}$ & 4 & 2 & 70 & 85 \\
\hline
\end{tabular}

${ }^{a}$ Conversion evaluated by comparison of the alkene vs epoxide $\mathrm{CH}$ signals in the ${ }^{\mathrm{I}} \mathrm{H}$ NMR spectrum; ${ }^{\mathrm{b}}$ ee determined by Chiral $\mathrm{GC}^{\mathrm{c}}$ ee determined by ${ }^{1} \mathrm{H}$ NMR spectroscopy in $\mathrm{CDCl}_{3}$ using $\left.[(+) \text {-Eu(hfc })^{3}\right]$ as the chiral shift reagent and tetramethylsilane as the internal standard

that this new system is just as active as that reported using oxone, and the level of enantioselectivity is similar, suggesting that background oxidation of the alkene substrate by the selenium oxidant does not occur.

In order to develop a more highly enantioselectve approach for epoxidation of unfunctionalized alkenes, we opted to employ the iminium salt catalysts $5^{14}$ and $\mathbf{6}^{2 \mathrm{w}}$ Again, the use of the diphenyldiselenide system compares well with the standard oxone conditions, with similar isolated yields and almost identical levels of enantioselectivity (Table 2). ${ }^{15}$

Very few reports have emerged of the amine-catalysed epoxidation of alkenes. Aggarwal in $2003^{16}$ and Yang in $2005^{17}$ independently reported employing oxone and a secondary amine, although both we and Lacour have shown that amines related to $7^{14}$ catalyse the epoxidation of unfunctional alkenes. ${ }^{18}$ In these reactions, unlike those reported by Aggarwal and Yang, which are believed to occur through hydrogen bonding to persulfate, oxone

Table 3 Highly enantioselective epoxidation of substrates using amine 7 as precatalyst ${ }^{\mathrm{a}}$

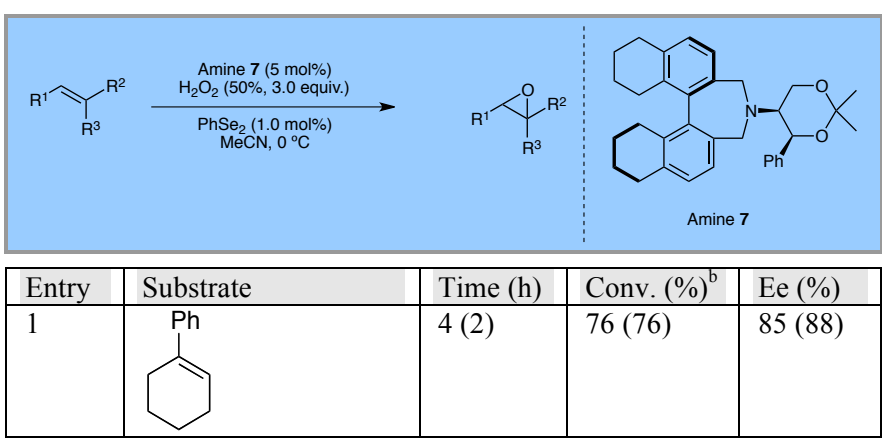

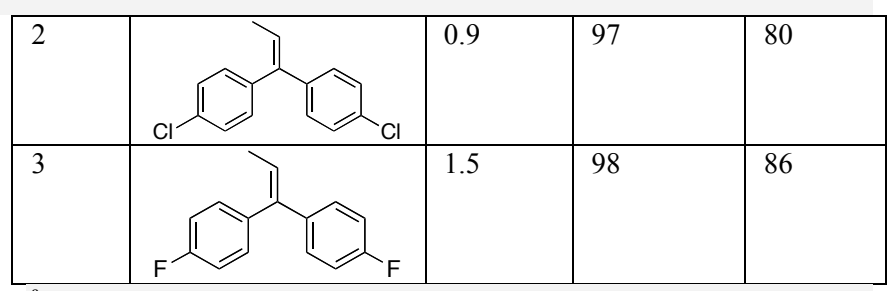

${ }^{a}$ Amine 7 (5 mol\%), $\mathrm{H}_{2} \mathrm{O}_{2}$ (50\%, 3.0 equiv.), $\mathrm{PhSe}_{2}$ (1.0 mol\%),

$\mathrm{MeCN}, 0{ }^{\circ} \mathrm{C} ;{ }^{\mathrm{b}}$ Conversion evaluated by comparison of the alkene vs epoxide $\mathrm{CH}$ signals in the ${ }^{1} \mathrm{H}$ NMR spectrum.

converts the amines firstly to the iminium and subsequently to the oxaziridinium ions, thus enabling epoxidation to proceed.

We were interested to discover if this was also possible using the diphenyldiselenide/hydrogen peroxide system. Thus, amine 7 was subjected to the conditions outlined in Table 3. Excellent yields and enantioselectivities were obtained and were almost identical to those observed using the corresponding iminium salt.

A plausible dual catalytic cycle is outlined in scheme 5: benzeneperseleninic acid ${ }^{19}$ generated from hydrogen peroxide in turn oxidizes the iminium ion, thus generating the oxaziridinium ion required for enantioselective oxygen transfer to the alkene. The benzeneseleninic acid by-product is then reoxidized to the active oxidant by hydrogen peroxide. 


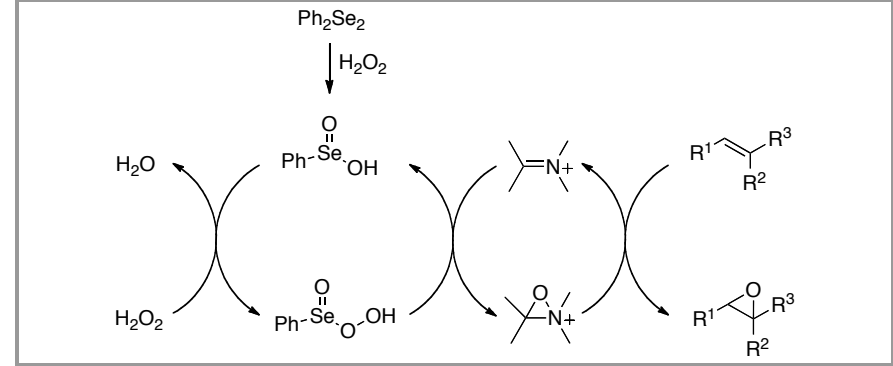

Scheme 4 A plausible dual catalytic cycle

In conclusion we have demonstrated for the first time that perseleninic acid derived in situ from diphenyldiselenide and hydrogen peroxide is a useful oxidant system for oxaziridinium salt-catalysed epoxidation. The reaction rates and ees are similar to those observed when oxone is used as a stoicheiometric oxidant, but this system benefits from a simple work up and no inorganic waste products, offering an attractive alternative to more standard approaches.

\section{Acknowledgment}

This investigation has enjoyed the support of Eli Lilly and the EPSRC (CASE award to C.E.), Loughborough University and the University of East Anglia. We are indebted to The Royal Society for an Industry Fellowship (to P.C.B.P.), Research Councils UK for a RCUK Fellowship (to B.R.B.), and to the EPSRC National Mass Spectrometry Facility, Swansea.

\section{References}

(1) (a) Page, P. C. B.; Rassias, G. A.; Barros, D.; Ardakani, A.; Bethell, D.; Merifield, E. Synlett 2002, 580; (b) Page, P. C. B.; Barros, D.; Buckley, B. R.; Blacker, A. J.; Marples, B. A. Tetrahedron: Asymmetry 2005, 16, 3488; (d) Page, P. C. B.; Buckley, B. R.; Rassias, G. A.; Blacker, A. J. Eur. J. Org. Chem. 2006, 803; (e) Page, P. C. B.; Buckley, B. R.; Barros, D.; Blacker, A. J.; Heaney, H.; Marples, B. A. Tetrahedron 2006, 62, 6607; (g) Page, P. C. B.; Buckley, B. R.; Farah, M. M.; Blacker, A. J. Eur. J. Org. Chem. 2009, 3413; (h) Page, P. C. B.; Bartlett, C. J.; Chan, Y.; Day, D.; Parker, P.; Buckley, B. R.; Rassias, G. A.; Slawin, A. M. Z.; Allin, S. M.; Lacour, J.; Pinto, A. J. Org. Chem. 2012, $77,6128$.

(2) (a) Picot, A.; Milliet, P.; Lusinchi, X. Tetrahedron Lett. 1976, 17, 1573; (b) Milliet, P.; Picot, A.; Lusinchi, X. Tetrahedron Lett. 1976, 17, 1577; (c) Hanquet, G.; Lusinchi, X.; Milliet, P. Tetrahedron Lett. 1987, 28, 6061; (d) Hanquet, G.; Lusinchi, X.; Milliet, P. Tetrahedron Lett. 1988, 29, 3941; (e) Bohe, L.; Hanquet, G.; Lusinchi, M.; Lusinchi, X. Tetrahedron Lett. 1993, 34, 7271; (f) Bohe', L.; Lusinchi, M.; Lusinchi, X. Tetrahedron 1999, 55, 141; (g) Bohe', L.; Kammoun, M. Tetrahedron Lett. 2002, 43, 803; (h) Bohe, L.; Kammoun, M. Tetrahedron Lett. 2004, 45, 747; (i) Aggarwal, V. K.; Wang, M. F. Chem. Commun. 1996, 191; (j) Armstrong, A.; Ahmed, G.; Garnett, I.; Gioacolou, K. Synlett 1997, 1075; (k) Armstrong, A.; Ahmed, G.; Garnett, I.; Gioacolou, K.; Wailes, J. S. Tetrahedron 1999, 55, 2341; (1) Gluszynska, A.; Mackowska, I.; Rozwadowska, M. D.; Sienniak, W. Tetrahedron: Asymmetry 2004, 15, 2499; (m) Biscoe, M. R.; Breslow, R. $J$. Am. Chem. Soc. 2005, 127, 10812; (n) Minakata, S.; Takemiya, A.; Nakamura, K.; Ryu, I.; Komatsu, M. Synlett 2000, 1810; (o) Wong, M.-K.; Ho, L.-M.; Zheng, Y.-S.; Ho, C.- Y.; Yang, D. Org. Lett. 2001, 3, 2587; (p) Cros-

\section{(a) Page, P. C. B.; Rassias, G. A.; Barros, D.; Bethell, D.;}

Schilling, M. B. J. Chem. Soc., Perkin Trans. 1 2000, 3325. Page, P. C. B.; (b) Rassias, G. A.; Barros, D.; Ardakani, A.; Buckley, B.; Bethell, D.; Smith, T. A. D.; Slawin, A. M. Z. J. Org. Chem. 2001, 66, 6926.

(4) http://www2.dupont.com/Oxone/en US/

(5) Campestrini, S.; Di Furia, F.; Labat, G.; Novello, F. J. Chem. Soc., Perkin Trans. 2 1994, 2175.

(6) Page, P. C. B.; Barros, D.; Buckley, B. R.; Ardakani, A.; Marples, B. A. J. Org. Chem. 2004, 69, 3595.

(7) Page, P. C. B.; Buckley, B. R.; Heaney, H.; Blacker, A. J. Org. Lett. 2005, 7, 375.

(8) Page, P. C. B.; Appleby, L. F.; Day, D.; Chan, Y.; Buckley, B. R.; Allin, S. M.; Mckenzie, M. J. Org. Lett. 2009, 11, 1991.

(9) Bartlett, C. J.; Day, D. P.; Chan, Y.; Allin, S. M.; McKenzie, M. J.; Slawin, A. M. Z.; Page, P. C. B. J. Org. Chem. 2012, 77, 772.

(10) Page, P. C. B.; Parker, P.; Rassias, G. A.; Buckley, B. R.; Bethell, D. Adv. Synth. Catal. 2008, 350, 1867.

(11) Page, P. C. B.; Parker, P.; Buckley, B. R.; Rassias, G. A.; Bethell, D. Tetrahedron 2009 65, 2910.

(12) Brodsky, B. H.; Du Bois, J. J. Am. Chem. Soc. 2005, 127, 15391.

(13) ten Brink, G.-J.; Vis, J.-M.; Arends, I. W. C. E.; Sheldon, R. A. J. Org. Chem. 2001, 66, 2429-2433; ten Brink, G.-J.; Fernandes, B. C. M.; van Vliet, M. C. A.; Arends, I. W. C. E.; Sheldon, R. A. J. Chem Soc., Perkin Trans. 1 2001, 224.

(14) 2,2'-bis-(Bromomethyl)-octahydrobinaphthalene was prepared according to the method of Ruan. ${ }^{20}$ The dibromide $(0.20 \mathrm{~g}, 0.45 \mathrm{mmol})$ and $(S, S)$-acetonamine $(0.20 \mathrm{~g}$, $0.45 \mathrm{mmol})$ were dissolved in acetonitrile $(30 \mathrm{~mL})$, and potassium carbonate $(0.185 \mathrm{~g}, 1.34 \mathrm{mmol})$ added. The solution was stirred with heating under reflux for $4 \mathrm{~h}$. After cooling to room temperature, the solvent was removed under reduced pressure. The residue was dissolved in dichloromethane $(30 \mathrm{~mL})$, washed with water $(2 \times 30 \mathrm{~mL})$, dried $\left(\mathrm{MgSO}_{4}\right)$, filtered and solvents removed under reduced pressure to afford 7 as a colourless solid $(0.20 \mathrm{~g}$, 91\%); m.p. $170-171{ }^{\circ} \mathrm{C} ;[\alpha]^{20}{ }_{D}-8.4\left(\mathrm{c} 0.9, \mathrm{CH}_{2} \mathrm{Cl}_{2}\right)$; Found: C, 82.52; H, 7.66; N, 2.92; $\mathrm{C}_{34} \mathrm{H}_{39} \mathrm{NO}_{2}$ requires $\mathrm{C}$, 82.72; H, 7.96; N, $2.84 \%$; $v_{\max }$ (film)/cm-1 3052, 2932, 1633, 1599, 1449, 1443, 1388, 1300, 1200, 1142, 1109 , 950, 850, 731; ${ }^{1} \mathrm{H} \mathrm{NMR}\left(400 \mathrm{MHz}, \mathrm{CDCl}_{3}\right): \delta_{\mathrm{H}} 1.59(3 \mathrm{H}$, $\mathrm{s},), 1.64(3 \mathrm{H}, \mathrm{s}), 1.74-1.78(8 \mathrm{H}, \mathrm{m}), 2.12-2.19(2 \mathrm{H}, \mathrm{m})$, 2.62-2.65 (3 H, m), $2.85(4 \mathrm{H}, \mathrm{t}, \mathrm{J} 6.8 \mathrm{~Hz}), 3.10(2 \mathrm{H}, \mathrm{d}, \mathrm{J}$ $12.4 \mathrm{~Hz}), 3.50(2 \mathrm{H}, \mathrm{d}, \mathrm{J} 12.0 \mathrm{~Hz}), 4.11-4.23(3 \mathrm{H}, \mathrm{m}), 6.90$ $(2 \mathrm{H}, \mathrm{d}, \mathrm{J} 7.2 \mathrm{~Hz}), 6.99(2 \mathrm{H}, \mathrm{d}, \mathrm{J} 7.2 \mathrm{~Hz}) \mathrm{ppm} ;{ }^{13} \mathrm{C} \mathrm{NMR}$ $\left(100 \mathrm{MHz}, \mathrm{CDCl}_{3}\right): \delta_{\mathrm{C}} 19.2,22.7,22.8,23.0,23.1,27.6$, 27.7, 29.5, 29.6, 52.8, 59.9, 61.3, 125.9, 126.7, 127.6, $128.0,132.3,133.5,154.9,137.8,158.1,138.7 ; \mathrm{m} / \mathrm{z}(\mathrm{ESI})$ 494.3043; $\mathrm{C}_{34} \mathrm{H}_{40} \mathrm{NO}_{2}\left[\mathrm{M}^{+} \mathrm{H}\right]$ requires 494.3059 . Compound 7 (0.08 g, $0.16 \mathrm{mmol})$ was dissolved in dichloromethane $(20 \mathrm{~mL})$ and $N$ - bromosuccinimide $(0.04 \mathrm{~g}$, $0.19 \mathrm{mmol}, 1.2$ eq.) added. The solution was heated under reflux for $4 \mathrm{~h}$. After cooling to room temperature, the sol- 
vent was removed under reduced pressure. The residue was dissolved in ethanol, and sodium tetraphenylborate $(0.06 \mathrm{~g}$, $0.018 \mathrm{mmol}, 1.1$ eq.), dissolved in the minimum amount of acetonitrile, was added in one portion, and the reaction mixture stirred for $5 \mathrm{~min}$. The solvents were removed under reduced pressure to give a yellow residue that was recrystallized from hot ethanol to give $\mathbf{5}$ as a yellow crystalline solid, washed with cold ethanol and diethyl ether $(0.10 \mathrm{~g}$, 76\%), m.p. $130-135^{\circ} \mathrm{C} ;[\alpha]^{20}{ }_{\mathrm{D}}-10.0\left(\mathrm{c} 0.8, \mathrm{CH}_{2} \mathrm{Cl}_{2}\right)$; Found: $\mathrm{C}, 85.45 ; \mathrm{H}, 6.82 ; \mathrm{N}$ 1.63. $\mathrm{C}_{58} \mathrm{H}_{58} \mathrm{BNO}_{2}$ requires $\mathrm{C}$, 85.80; H, 7.20; N, $1.73 \% ; v_{\max }\left(\right.$ film) $/ \mathrm{cm}^{-1} 3053,2936$, $1619,1575,1488,1427,1382,1202,1111,838,733,703$; ${ }^{1} \mathrm{H}$ NMR $\left(400 \mathrm{MHz}, \mathrm{CDCl}_{3}\right): \delta_{\mathrm{H}} 1.55-1.62(6 \mathrm{H}, \mathrm{d}), 1.76-$ $2.27(12 \mathrm{H}, \mathrm{m}), 2.53-2.99(6 \mathrm{H}, \mathrm{m}), 3.45-3.71(3 \mathrm{H}, \mathrm{m})$, 5.00-5.05 (1 H, m), 6.73-6.78 (4 H, m), 6.84- 7.11 (10 H, m), 7.20-7.28 (8 H, m), 7-29-7.36 (8 H, m) ppm; ${ }^{13} \mathrm{C} \mathrm{NMR}$ $\left(100 \mathrm{MHz}, \mathrm{CDCl}_{3}\right) ; \delta_{\mathrm{C}}$ (mixture of rotamers) $14.2,18.8$, $18.9,21.0,21.8,22.1,22.2,22.5,22.8,22.9,23.3,26.8$, $27.8,27.95,28.02,29.5,29.6,29.7,29.6,29.7,30.2,30.6$, $30.9,48.4,54.8,55.2,60.4,60.5,63.2,66.4,71.7,73.8$, $99.1,100.4,122.3,124.1,124.7,124.8,125.1,125.4$, $125.8,125.8,125.9,127.1,128.0,128.2,128.4,128.6$, $128.8,128.9,129.0,129.7,130.5,131.7,133.8,134.1$, 134.6, 134.9, 135.2, 135.6, 135.8, 136.0, 136.1, 137.7, $138.8,139.8,140.4,140.5,144.0,144.6,146.3,187.0 ; \mathrm{m} / \mathrm{z}$ (EI) 492.2897; $\mathrm{C}_{34} \mathrm{H}_{38} \mathrm{NO}_{2}\left[\mathrm{M}^{+}\right.$, cation] requires 492.2895.

(15) General procedure for epoxidation using diphenyldiselenide, hydrogen peroxide and iminium salt or amine: The alkene (1.0 equiv.) was dissolved in acetonitrile ( $2 \mathrm{~mL}$ per mmol alkene), the iminium salt (or amine) catalyst ( $5 \mathrm{~mol} \%$ ) was added along with diphenyldiselenide ( $1 \mathrm{~mol} \%)$. The reaction vessel was cooled in an ice bath for 5 minutes before hydrogen peroxide $(50 \%$, 3.0 equiv.) was added dropwise over 5 minutes. The reaction progress was followed using thin-layer chromatography and when the reaction was complete, diethyl ether $(20 \mathrm{~mL})$ was added. The mixture was washed twice with water and once with saturated brine and dried over $\mathrm{MgSO}_{4}$. The solvents were removed under reduced pressure and the crude product was purified using column chromatography on silica gel (ethyl acetate/petroleum ether/triethylamine).

(16) Aggarwal, V. K.; Lopin, C.; Sandrinelli, F., J. Am. Chem. Soc. 2003, 125, 7596.

(17) Ho, C.-Y.; Chen, Y.-C.; Wong, M.-K.; Yang, D., J. Org. Chem. 2005, 70, 898.

(18) (a) Gonçlaves, M.-H.; Martinez, A.; Grass, S.; Page, P. C. B.; Lacour, J. Tetrahedron Lett. 2006, 47, 5297; (b) Page, P. C. B.; Farah, M. M.; Buckley, B. R.; Blacker, A. J.; Lacour, J. Synlett 2008, 1381; (c) Vachon, J.; Lauper, C.; Ditrich, K.; Lacour, J. Tetrahedron:Asymmetry 2006, 17, 2334.

(19) Grieco, P. A.; Yokoyama, Y.; Gilman, S.; Ohfune, Y. J. Chem. Soc., Chem. Commun. 1977, 870.

(20) Ruan, J.; Lu, G.; Xu, L.; Li, Y. M.; Chan, A. S. C. $A d v$. Synth. Catal. 2008, 350, 76. 
Graphical Abstract:

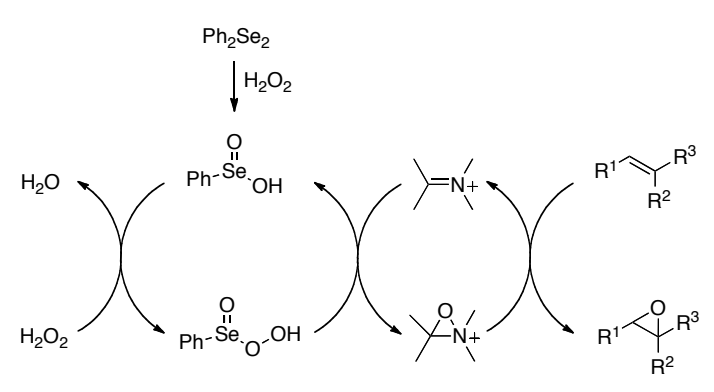

Short Title:

Activation of Hydrogen Peroxide by Diphenyl Diselenide: Highly Enantioselective Catalytic Asymmetric Epoxidation

Please place the graphical abstract and short title of the article here. The short title will be used as a running header. Manuscript submission checklist

- Statement of significance of work.

- Full mailing address, telephone and fax numbers, and email address of the corresponding author.

- Paper save as a PDF file.

- Original Word file.

- Original graphic files.

- Graphical abstract. 